\title{
Sport as a Means of Governing Social Integration: Discourses on Bridging and Bonding Social Relations
}

David Ekholm

The self-archived postprint version of this journal article is available at Linköping University Institutional Repository (DiVA):

http://urn.kb.se/resolve?urn=urn:nbn:se:liu:diva-1563.56

N.B.: When citing this work, cite the original publication.

Ekholm, D., (2019), Sport as a Means of Governing Social Integration: Discourses on Bridging and Bonding Social Relations, Sociology of Sport Journal, 36(2), 152-161.

https://doi.org/10.1123/ssj.2018-0099

Original publication available at:

https://doi.org/10.1123/ssj.2018-0099

Copyright: Human Kinetics

http://www.humankinetics.com/europe 


\title{
Sport as a means of governing social integration: discourses on bridging and bonding social relations
}

\author{
David Ekholm, Linköping University
}

\begin{abstract}
This article analyzes how representatives of two sports-based interventions in Sweden conceptualize the ways in which different forms of social relations facilitate social inclusion and integration. The articulated statements are analyzed from a discursive and governmentality perspective. The discourse spotlights how sports practices ideally provide inclusive and bridging meetings between schools and children from different areas, and how bonding relations with formative role-models make it possible to reach out to young people in the community and to facilitate learning, guidance and social change according to certain norms. However, bonding relations between children from the same area are not spotlighted in discourse. This, and other discursive effects, are problematized with respect to how such discourse restrains and limits the conditions for the social inclusion and integration of the targeted youth.
\end{abstract}

\section{INTRODUCTION}

This article deals with how sport is constructed as a means of social inclusion and integration, focusing on how various forms of social relations are conceptualized in statements and manifested in discourse. Empirically, the article is based on a study in which two sports-based interventions were followed and representatives of the interventions were interviewed: Football for Inclusion and The Sport Program, conducted in public-private partnership involving, among other actors, schools and local sport clubs, in a disadvantaged suburban area in a mid-sized city in Sweden.

\section{Background and social policy context}

Following the challenges and problems of segregation throughout Western societies, often represented in media and policy articulation in relation to migration and the integration of minorities (Dahlstedt \& Neergard, 2016), sport and leisure activities have been highlighted in social policy (as well as in scientific discourse) as an arena where social relations can be formed and social capital developed, in turn facilitating social inclusion and integration (Coalter, 2007; Collins \& Haudenhuyse, 2015; Morgan, 2013; Spracklen, Long \& Hylton, 2015; Verhagen \& Boonstra, 2014). However, both the notions that sport and leisure activities are suitable means of promoting social relations and social capital (Coakley, 2011; Collins \& Haudenhuyse, 2015) and that social capital leads to social integration (Blackshaw \& Long, 2005), are contestable.

In recent decades, growing economic inequalities have created geographical divisions in the urban landscapes in Sweden. This development has underpinned ethnic segregation, as the concentration of migrants and residents with foreign backgrounds in certain suburban areas is exceptionally high (Andersson, 2013). Today, there is a steady increase in the number of socially vulnerable residents, particularly young people with a migrant background, living in underprivileged and stigmatized suburban residential areas (Sernhede, 2011). It is within this context that social policy objectives aimed at social inclusion and integration have gained increasing attention (Dahlstedt \& Ekholm, 2019). Since the 1960s and 1970s, Swedish social and integration policy has been renowned for its basis in multiculturalism (Schierup, 2010). The discourse on multiculturalism has upheld principles of diversity, equality and citizenship, stressing that migrants should have similar living conditions and rights as the rest of the population and that migrants were supported in sustaining cultural diversity (Ålund \& Schierup, 1991). However, notions of multiculturalism and diversity have been challenged over the last decade by a political 
discourse emphasizing cultural unity and stressing that European societies, as well as society in Sweden, have become too diverse (Schierup, Ålund \& Neergard 2017). In Sweden specifically, there has been a recurrent debate about the essence of and adaption to "Swedish values" (Dahlstedt \& Eliassi 2018). This debate have been underpinned by a discourse of social exclusion (or the "problem of the outside") and various policy measures to promote social inclusion have been organized, targeting ethnic and cultural minorities, primarily adolescents, in suburban residential areas (Dahlstedt \& Ekholm, 2019). In relation to this development, young people living in under-privileged and stigmatized suburban areas have been problematized for reinforcing their perceived social exclusion when developing social bonds within their local and cultural community (Ekholm \& Dahlstedt, 2018).

In Sweden, the role of sport in promoting social inclusion and integration, and countering social exclusion and marginalization, was particularly underscored by national government agencies following a peak in immigration numbers during 2015 (Fundberg, 2017). Importantly, sports practices such as sports-based programs utilized for integration and social policy objectives, are often formed in public-private partnerships. Such cross-sectoral forms of organization have been used as a way to involve civil society in welfare provision (Dahlstedt, 2009; Ekholm \& Dahlstedt, 2018) and to revitalize welfarist governmental rationality in contemporary advanced liberal societies (cf. Rose, 1999; Villadsen, 2008). Sweden is just one among many countries where sport has been highlighted in this respect (Ekholm, 2013).

\section{Aim and research questions}

In this article, discourses on how the interventions contribute to integration and social inclusion, and how sport, in general, is conceived of as a means of social integration, are investigated. An obvious and recurrent theme in the statements articulated and examined concern different forms of social relations and how the variety of social relations presumably facilitate social inclusion and integration; a discourse that in many respects resonates with social policy and scientific discourse. The aim of this article is to analyze how representatives of the observed sports-based interventions conceive of the way in which social relations facilitate social inclusion and integration by means of youth sport participation. The following research questions are investigated: How are social inclusion and integration constructed and conceptualized in discourses about the interventions being promoted? How are social relations conceptualized as means of governing social inclusion and integration within the interventions? What discursive effects underpinning governing interventions are made possible by these constructions and conceptualizations? These questions are investigated from a governmentality perspective, highlighting the relations between representations of the problems and how governing by means of facilitating social relations, social inclusion and integration are formed. In particular, the article elaborates upon how discourses and conceptualizations of social relations and integration underpin the rationales of governing social inclusion and integration with which the intervention practices are imbued.

\section{RESEARCH CONTEXT AND CONTRIBUTIONS}

Social relations are notably a recurrent theme in the research literature and scientific discourse on sport and social inclusion or integration (cf. Ekholm, 2013). Perceived links between social relations, social integration and youth sport participation have been investigated, particularly with respect to social capital development (e.g. Baily, 2005; Coalter, 2007; Elmose-Østerlund \& van der Roest, 2017; Nicholson \& Hoye, 2008; Seippel, 2006; Vermeulen \& Verweel, 2009).

\section{The significance of Putnamian approaches to social integration in scientific discourse}

Although criticized for lacking substantial empirical foundations and for instilling particular ideological and normative implications (cf. Blackshaw \& Long, 2005), Putnam's theorizations of 
social capital and on the relation between social capital and social integration have gained a certain recognition within the sociology of sport (cf. Bailey, 2005; Elmose-Østerlund \& van der Roest, 2017; Nicholson \& Hoye, 2008; Vermeulen \& Verweer, 2009) - notably, providing a language of description and representation, and a frame for understanding social relations and social integration (cf. Blackshaw \& Long, 2005). This particular perspective, beyond being influential in the sociology of sport and in policy debate, is important to highlight here.

Articulations and forms of knowledge, about how integration is pursued in the two sports-based interventions investigated in this article, will be noted to align in certain respects with concepts embedded in the Putnamian approach to social relations and social capital development.

In brief, Putnam's $(1993,2000)$ argument is that participation in voluntary practices and civil society activities, such as sport, introduces people to social relations and forming social networks. Such social relations create trust and reciprocity between people - in this sense, social capital is the integral resource embedded within these networks. Social capital, from this point of view, is developed as bridging or bonding social capital. Bridging social capital means the development of relations and networks with people from other environments and backgrounds, people who are different from oneself. Sometimes these relations are referred to as inclusive bridging (cf. Coakley, 2011), forming inclusive networks beyond the limits of one's own community. From this point of view, bridging social capital is essential in terms of forming social cohesion within broad populations. Bonding social capital means the development of relations and networks with people from similar environments and backgrounds who are part of the same community. Sometimes these relations are referred to as exclusive bonding (cf. Coakley, 2011), highlighting that bonds are strengthened within the exclusive community and in that sense contribute to segregation and exclusion from wider society. Accordingly, moral relations between active, voluntary and autonomous people constitute a social glue holding society together; and it is this social glue, a metaphor for social capital, that could be conceived of in terms of social cohesion and integration. This particular approach provides a theorization of how social cohesion and integration may be formed in contemporary society. Notably, this means that participation in sport and involvement in community and civil society establishes social networks, social relations and ultimately bridging or bonding social capital, which, in turn, constitutes a social glue holding people and society together.

\section{The potential of bonding social capital}

Most notably, in scientific discourse, there is a certain emphasis on the potential for sport to provide people with bonding social capital. It is evident that sport may facilitate the development of bonding social capital rather than bridging social capital (Spracklen et al., 2015; Theebom, Schaillée \& Nols, 2012; Walseth, 2008). Local sports practices in civil society organizations are important for young people in terms of gaining both formal and informal social relations (Cuskelly, 2008), although, in sport, youth often participate in activities with other young people from their own community (Auld, 2008). This strengthens bonds and may form deeper relations with peers within the community (Theebom et al., 2012). This is of especial importance for participants experiencing marginalization and social exclusion (Walseth, 2016). For instance, this is the case for relations between marginalized youngsters and role models within the same community (Richardson Jr., 2012). Moreover, bonding relations through participation in sport have been of particular importance for people who share traumatic experiences (Walseth, 2016).

Notably, bonding social capital is important with respect to identity formation among minorities. Peer relations forms an arena within which new identities can be negotiated with respect to the use of cultural symbols and negotiating positions between national and cultural belonging (Vermeulen \& Verweel, 2009; Walseth, 2016). Moreover, Walseth (2008) argues that participation in sport may provide opportunities for minorities to bridge social relations with other minority groups, but only to a lesser degree provides bridges to young people from more privileged socio- 
economic groups. Widdop, Cutts and Jarvie (2016) highlight that participation in sport may grant access to disparate social capital depending on a range of structuring variables, noting that sociological analysis needs to take into account individuals' tendency to bond with others in similar positions in the social structure.

Although they emphasize bonding social capital, Verhagen and Boonstra (2014) underscore that participation in sport may also form an introduction to bridging relations in associations, with people in and around activities, when the social climate supports mutual and coequal social interaction. Similarly, Harvey, Lévesque and Donnelly (2007) stress that social capital development requires long-term involvement in activities in order for relations to develop and for networks to be established. In contrast, Hoye, Nicholson and Brown (2015) note that even short-term involvement may lead to increased social connectedness within the community, and Spaaij (2012) underlines the importance of organizational arrangements making networks possible to reach. Elmose-Østerlund and van der Roest (2017) critically question the presumed links between participation in sport and the kind of social trust and reciprocity that is anticipated from capital development.

\section{Potentially segregating and excluding dimensions of youth participation in sport}

From a political point of view, bonding relations are often conceived of as exclusive and segregating and therefore it has been difficult for associations to be granted public funds for sport for inclusion interventions (Walseth, 2016). In contrast to the view promoted by such policy, Vermeulen and Verweel (2009) point out that, although participation in sport facilitates bonding interactions, this is not particular only to marginalized youth or minority groups; therefore, it is highly problematic to stress such a concern and that bonding capital leads to exclusion from the rest of society, merely when it comes to the formation of bonding capital among those suffering from marginalization. Here, as Janssens and Verweel (2014, p. 55) stress, "policymakers should therefore accept and support separate clubs in the same way they cherish the mixed ones", and that bonding relations as well as bridging relations are important for creating integration and reciprocity. Also, Spracklen et al. (2015) note that sport is no exception to other social spheres when it comes to questions of inclusion and exclusion. There are most notably processes of othering that form distinctions and social exclusion within sports practices. Also, Vandermeerschen, van Regenmortel and Scheerder (2017) highlight that youth in poverty often feel excluded from sport and therefore are not able to benefit from participation. Access to cultural capital, something that migrants, for instance, may lack, could be seen as a resource that is needed even to be informed about how sports practices are carried out (Spracklen et al., 2015). Access to the right accumulation of capital may enable a transition from recreational sports to formal club and competitive sports (Rosso \& McGrath, 2013). Altogether, concerns about limitations regarding bridging potential and exclusionary processes within sport make assumptions about the perceived links between participation in sport, social capital development and social integration contentious (cf. Coalter, 2007; Morgan, 2013).

\section{Notions of social capital as a means of integration: a force in social policy}

In recent decades, the discourse of social capital development and its perceived links to social integration - even with a particular focus on sport as a proxy for civil society - has gained significant recognition in social policy (Bailey, 2005; Coalter, 2007; Nicholson \& Hoye, 2008; Verhagen \& Boonstra, 2014; Vermeulen \& Verweer, 2009). Blackshaw and Long (2005) explain this by spotlighting the normative communitarian discourse embedded within this particular theorization. They note how this discourse matches closely with the political agenda of active citizenship, civic morality, community and civil society as dimensions of the deliberative and communitarian democracy which is integral to New Labour's Third Way policy agenda (Coalter, 2007) and in relation to the liberal and conservative Big Society agenda (Morgan, 2013) in the $\mathrm{UK}$, and that have influenced welfare states since. 
Accordingly, the discourse on social relations, social capital and social integration is a performative force of social policy. This means that discourses about how social relations are perceived to facilitate social capital and social integration provide a framework for governmental practices. The intersection between discourse as a form of knowledge and governmental practices as a form of exercising power stresses the importance of analyzing power and practices of governing by targeting the notions and discourses - the knowledges - embedded in such practices. The overview presented in this section has provided insights into research about how, and under what conditions, sport may constitute a venue for practices in which social relations are formed and social capital in a variety of forms can be developed. It is an urgent task to problematize and critically interrogate the discourse of social capital and social integration in relation to sports practices and policy objectives. Not primarily in order to decide the empirical evidence for such links; but rather, in order to scrutinize the power effects of governing that this knowledge and discourse enable and instill. This is a point of recognition for conducting a critical analysis of the discursive and governing effects enabled when formulating policy in practice and in performing sports-based social interventions. Using concepts of social capital and integration to make visible how knowledge about social policy and sports-based interventions are conceived and articulated does not mean to uncritically embrace the theoretical underpinnings and notions of links between them ontologically; instead, such concepts are used to make clear how a certain discourse could be formed, which is important for analyzing the power effects that such a discourse enables.

\section{THEORETICAL AND METHODOLOGICAL FRAMEWORK}

In this article, discourses on social relations intertwined with governing social inclusion and integration are interrogated. Accordingly, discourse is viewed as an integral dimension of governing practices, enabling conceptual understandings of inclusion and integration, in turn guiding and making possible certain governing interventions.

\section{Governmentality and discourse analysis}

Discourse, here, refers to a structure of interrelated statements and practices, gaining status as knowledge, animating the objects and reality they mean to describe (Bacchi, 2009; Foucault, 1971, 1980). Consequently, discourse makes reality manifest in a certain way and enables, for instance, subjects and social relations to be thought about and acted upon in accordance with a particular rationale. Here, the concept of productive power is vital. Statements and discourse - knowledge, that is - are performative and productive, shaping both the frames of interpretation and the actual practices specified on the basis of such knowledge. Accordingly, power "traverses and produces things, it induces pleasure, forms knowledge, produces discourse [and thus] needs to be considered as a productive network which runs through the whole social body" (Foucault 1980: 119). As a result, the objects animated are made governable (Bacchi, 2009; Dean, 2010; Foucault, 1982). This also means that discourse institutes limitations on how objects and reality, subjects and social relations can be thought about, forming discursive exclusions and regulating what cannot be thought about or articulated (Foucault, 1971). The ways of understanding reality, the governing interventions as well as the regulations limiting how subjects, social relations and integration can be understood, are seen as discursive effects (Bacchi, 2009). Here, scientific discourse and knowledge, encouraged by policy-making agencies, is particularly important in forming regimes of truth to be acted upon in social policy (Foucault, 1980; Rose, 1999). In this respect, regimes of truth and the practice of sport as a means of social inclusion and integration by facilitating social relations and developing social capital are a historical and political discourse and construct, enforced in confrontation and competition with other discourses. Accordingly, discourse is not stable or fixed but contingent, and should therefore not be taken for granted but rather analytically problematized or deconstructed (Bacchi, 2009; Dean, 2010; Foucault, 1971, 1980; Rose, 1999). 
Conceptually, governing refers to "the conduct of conduct" (Foucault, 1982). This means that governing entails activities that shape and guide the actions, behaviors and subjectivities of others (cf. Dean, 2010; Rose 1999). The term signifies a concept of power, stressing the processes whereby subjects are guided in certain directions, participating in the processes (Foucault, 1982; Dean, 2010). A general objective of welfare states and governing social policy interventions are to promote social inclusion and integration. By means of various interventions, agencies and actors seek to guide and shape subjects into becoming included or includable citizens (Philp, 1979). Here, civil society has a prominent position in modern and advanced liberal social policy (Foucault, 2010; Rose, 1999), formed as an arena where governing interventions can be performed "at a distance" from the state and the public sector (Rose, 1999). In practice, this means that the actors and agencies of civil society have been increasingly integrated into governing interventions and practices (in public-private partnerships), coined as sites of the voluntarism and authentic social relations that are seen to be vital for civic democracy and social inclusion (Villadsen, 2008). Focusing on the governmental rationality of such interventions means to shine the spotlight on how governing is performed using civil society as a target and platform of governing: that is, to examine the knowledges intertwined in practices, the technologies performed to steer the conduct of young people, the ideals and objectives of governing and the subjectivities shaped by governing measures (Rose, 1999; Villadsen, 2008).

\section{Procedures in analysis}

Analyzing discourse and governing, accordingly, means to critically problematize how subjects and social relations are constructed in statements, enabling ways to think about and act upon them, and to critically assess the effects of power and governing enabled by such animations (Bacchi, 2009; Dean, 2010). In this article, statements articulated in interviews by representatives of the two sports-based interventions constitute the empirical material. In practice, the analytics of discourse and governing that are deployed could be described in three steps. First, analytical questions were formulated, guided by the conceptual and theoretical framework presented, highlighting how discourse and knowledge about subjects, social relations, social inclusion and integration are constructed and intertwined in governing practices. This move was informed by empirical observations of the material examined, containing recurrent statements and descriptions of the social relations associated with social integration. Second, guided by this framework, statements about various forms of social relations were thematically sorted and categories were constructed. Here, forms of social relations that were very similar and reminiscent of the discourse on bridging and bonding relations previously known and reported on in the research literature were noted. Such a distinction provided a language and frame for presenting the various forms of relations and interactions promoted in the statements examined. Third, on the basis of the categories constructed, analyses of the discourse and the governing rationality articulated within it were refined in greater detail. Here, the meaning and significance of, for instance, meeting-places and role-model interaction were explored in depth.

\section{EMPIRICAL MATERIAL EXAMINED: TWO SPORTS-BASED INTERVENTIONS}

The article is based empirically on two sports-based interventions that were followed between 2013 and 2018. Both programs were surveyed by means of interviews with representatives, managers, coaches, and partners as well as the examination of policy documentation. Both programs are conducted in the same socio-economically underprivileged area (the Area).

Football for Inclusion (FFI) is conducted jointly by three local sports associations in partnership with local schools and the municipal leisure and recreation administration. Financially, the program is supported by public funding, but also by charitable organizations and sponsorships. The aim is to "improve children's social and communicative competences and contribute to social inclusion, [to] activate children and youth [and to] facilitate friendship between children from different 
cultures". Here, children in the age range 8-12 play and practice football during school and afterschool activities. Moreover, the children and youth are offered help with homework. Activities are led by coaches and managers engaged and employed by the partnering sports clubs. A few of the coaches and the manager have qualifications in pedagogy and have previously worked professionally in schools and recreation centers, while other coaches are not trained professionals but have an active playing background in the clubs. The coaches constitute a diverse group with a variety of backgrounds, ages and genders. The program is currently expanding to other suburban areas in the city of origin.

The Sport Program (SP) is conducted by a social entrepreneur in partnership with local sports clubs and schools as well as the municipal administration for education. The program is financed primarily by public funding but is also supported by private sponsors. The aim of the program is to "reach out to children who are not active [...] gather up all young people in the risk zone, coach, educate and guide them to a better future". Here, children aged 11-16 are provided with opportunities to play a wide range of sports during school and in after-school activities as well as in holiday activities. The practices are led primarily by coaches who have practiced sport continuously in life but lack professional training in education or social work. The coaches, predominantly men aged between twenty and thirty, have experience of growing up in socioeconomically distressed, so-called areas of exclusion - something that is stressed in the analyzed discourse. The program started in the city that is observed here but has recently spread to five other cities.

The two interventions do not formally collaborate with each other. However, they are performed in the same area and to an extent with the same local sports clubs and schools involved.

Moreover, a few of the coaches associated with local sports clubs have been involved in both programs.

These two sports-based interventions were selected for analysis for three main reasons. First, the interventions represent a regime of practice utilizing sport as a means of meeting policy objectives aimed at making integration increasingly frequent in Sweden, in this respect pinpointing a new role for sports practices and sports organizations in Sweden. Second, they are typical of the form of public-private partnerships that have become more and more important in social policy in Sweden today, illustrating how actors in civil society become integrated into promoting policy objectives and how they adapt their rationales and practices to policy goals and expectations. Third, the design of these interventions has gained national recognition and similar interventions are currently performed in other parts of the original city (FFI) and in other municipalities in Sweden (SP), showing that the programs selected are perceived as important and innovative in wider contexts. Accordingly, gaining knowledge about and insight into the two interventions investigated may provide frames for further exploration of the role that sports practices have and can have in relation to social policy and integration.

The empirical material analyzed consists of statements articulated by coaches, managers and partners in both programs during interviews. In total, 20 semi-structured in-depth interviews were conducted. The respondents from the two programs included in the study were selected because they initiated the interventions, represent actors cooperating with the programs, have managed the program set-up or have worked with children in the actual sports practices. The selected respondents are the most well-informed persons working with or in cooperation with the two interventions. One recurrent theme in the statements concerned the variety of social relations associated with social inclusion and integration; therefore, this was highlighted in the analysis. 


\section{ANALYSIS}

In the statements and discourses that were articulated and examined, most notably two forms of relations are spotlighted. Although these are empirically recognized (the construction of these forms has not followed a theoretical predisposition), the language of bridging and bonding relations (noted in scientific discourse) is used analytically to describe them. Furthermore, these concepts are not articulated in the statements analyzed; however, the statements articulated in discourse follow a similar rationale and these constructs aid in presenting the analysis in an amenable way.

The analysis is presented in three subsections. First, statements on bridging and bonding social relations are interconnected with each other. In discourse, these are not mutually exclusive, but rather interrelated, forming a governmental underpinning discussed later (in the following section). Second, statements describing the sports-based interventions as bridging sites of inclusive meetings are reviewed. Here, it is emphasized that the sports practices ideally bring schools and children from different areas together, portraying the sports practices as bridges enabling a certain form of inclusive social networks and relations. Third, statements describing the sports-based interventions as sites of learning based on bonding relations with formative rolemodels are spotlighted in the material analyzed. Here, bonding social relations are viewed as a means of and condition for developing the skills needed to be included in society. Together, the various forms of social relations facilitating governing interventions are conceived of as providing opportunities for social inclusion and integration.

\section{Bridging and bonding rationales intertwined}

In the statements analyzed, discourses on bridging and bonding social relations intersect. Crucially, this has to do with young people's relations to, in one instance, other youth, and, in another instance, formative role-models. The sports-based interventions are portrayed as a site for promoting and facilitating both these kinds of social relations and, importantly, the geographical location of the governing interventions plays a key role in enabling this. In the following excerpt, the bridging and bonding rationales are demonstrated, by the SP manager, illustrating how they find a common geographical and institutional space within the intervention practice and the sports site.

We don't want to do basketball in four different schools just where you live, but instead, somewhere in the middle where all kids can meet. That is the reason we've focused not only on [the Area] in the school holiday activities, but that we wanted to introduce activities in different... that is in [the shopping mall]. And then, suddenly, it becomes natural for all. [Interviewer: Do children go there from other areas?] It was crammed. It would have been nice for you to see. Ok, so, they come from [Eastville, the Area, Southville], or from wherever. [...] I think, that if you go to the schools every year and the kids recognize you and they develop a sense of relation to you, so when you all of a sudden, in the school holidays, pass the shopping mall... they're like, "there's [the coach] over there". And, so, anyway, the kids have great trust and confidence in you... so it's much easier to create that. And that's really what we work with, to shape norms and values locally in school and then get the kids to adapt. (SP manager)

Here, the sports-based intervention, its practices and activities, is described as a place for meetings in general. Specifically, though, meetings and social relations between, first, young people from different geographical areas and social backgrounds, and second, between young people and coaches in their capacity as role-models are highlighted. Before this, the importance of geographical place, with respect to governing meetings, needs to be considered. Practices are arranged and located geographically so that children and youth from different suburban areas can participate, meet and interact with each other. The three areas mentioned are neighboring residencies in the southern parts of the city. Eastville is on the other side of the motor expressway from 'the Area' and the mall and is generally described as an affluent residential area, characterized by high income, well-functioning schools and local sport clubs as well as an 
ethnically native Swedish population. Southville, in contrast, located on the outskirts of the city, south of the Area and the shopping mall, is characterized by low-income households, a large migrant population and described as an area of exclusion.

With respect to the relations between different youth that were articulated, being located in close proximity and with spatial connections to the suburban commercial center, the mall is described as serving as a bridging site where young people from the different urban and socio-economic environments can meet and interact. In addition, with respect to relations between youngsters and coaches, by being visible there as well as in the local schools, influential coaches and rolemodels from the sport practices could gain recognition and credibility among children and youth - something that might eventually result in reciprocal relations and trust, which are important when it comes to affecting the conduct of young people. It is such bonding relations - based on shared experiences as well as similar backgrounds and cultural belonging within a community that is described as enabling role-models to reach out and influence children and youth morally, in order to facilitate social change.

\section{Bridging meetings between different children and youth facilitating social relations}

When respondents describe the sports-based interventions as sites of meetings, such discourse illustrates the kind of bridging social relations these interventions potentially facilitate. In the descriptions constituting a performative knowledge, this requires that the actual activities performed create opportunities for children and youth to meet with other children and youth from other parts of the city, so that the meetings themselves may break down social barriers and promote redeveloped social networks which altogether could constitute a social glue within society. In this sense, participation in sport is believed to lead to a kind of bridging social capital development which in turn manifests itself in social integration. In the following excerpt, the sports leader articulates how the FFI sports ground, the venue where the activities take place in the residential area, becomes a place of meetings.

This is a kind of practice where we can come together, to create more meeting places. On a sports site open to all. That is a good meeting place. [...] That is where you meet, and I believe that if we meet with each other many times, although we're from different cultures, I believe you start to respect and understand each other. (FFI, sports leader)

From this perspective, the activities, and thus the sports site, are described as being open to all children and youth - both within the residential area and also from other surrounding suburban areas. When meetings take place with children and youth from different cultural backgrounds, according to this particular discourse, the interaction presumably facilitates respect and mutual understanding. The potential tensions and conflicts that need to be responded to are represented in terms of culture and cultural difference, something that could presumably be addressed and overcome through meeting venues and bridging social relations. In a similar way, the recreational worker (in practice acting as a conductor of social inclusion and integration) in one of the partnering schools of FFI describes, with respect to meetings between schools, that it becomes possible for the children "to understand that we all have different baggage and that we come from different social contexts, which means that we deal with situations differently", and that the meetings taking place make it possible to "get to know about others" situations, which gives a greater understanding... and that is where the integration is". Importantly, these articulations involve a notion that meetings between young people from different areas and background may break down the rivalry and boundaries between them. For instance, the SP manager stresses that it is important "to reach out to schools in both prosperous and the more deprived" areas, in order to "get them to meet with each other". He underlines that it is in this context that "kids can meet" and "the idea is that this is what solves the problems with integration and xenophobia if one interacts at a young age across the social boundaries". In addition, the teacher involved in FFI highlights how "children learn to cooperate with children from different classes and schools 
that previously were like rival schools" and that FFI "is now breaking down these barriers and boundaries".

Consequently, according to the rationale displayed here, it is the bridging meetings that broaden the social networks of the children and youth involved. Moreover, in the words of the teacher associated with FFI, the sports-based intervention is claimed to even provide a site where "coaches, pedagogues, school administrators, children and parents meet and cooperate without problems". In the following excerpt, the SP manager, focusing on young people's meetings and social relations but also touching upon relations between teachers, coaches and associations, describes how the program is a venue for bridging meetings and relations.

As I often say, that integration can be in different ways. Most often, when you talk about integration, you think about immigrant and Swede. That is really... that is, we've seen, just when we have gatherings and schools meet together and see each other... there are many teachers who have never met, and now they meet within [the SP]. Same thing with the children. Same thing with the sports clubs. You know, there are some clubs... that's what came to mind... shit, the coaches... we had a meeting and so the meeting ended, and we were downtown. And so, I walked another route, and so I saw two club coaches walking together, going for coffee... And, just then, I thought... shit, these two would never have met if it wasn't for [the SP]. (SP manager)

Here, the manager narrates how new relations have developed that would not have been possible (or thinkable) if it was not for the context that the sports-based intervention provides. In the statement, integration is not limited to what is perceived as a traditional conceptualization based on overcoming the distinction between migrant and Swede; rather, social integration is more associated with expanding networks and enabling interpersonal relations. Interpersonal relations and meetings are not only a benefit accruing to the children and youth, it is also an opportunity for local schools, teachers, sports associations and, apparently, coaches from different sports and clubs. Notably, in the view presented constituting a particular form of knowledge, social relations are the result of meetings between persons and actors, in turn, resulting in social integration. There seems to be a clear governing rationale for the intervention, that meetings result in mutual relations and widened networks, forming integration.

This view is supported by the municipal councilor who chairs the municipal executive committee and who is particularly engaged in the sports-based interventions investigated here. In the following excerpt, the municipal councilor expounds on how sport, talking about the SP, offers a context in which people can meet as equals and relations can be established, forming a social glue holding society together.

So, sports have always been the kind of practice where you can meet, even if you have big differences in life in general. And that could be what makes community a bit special. [...] Despite the divisions, we are not that very different, and on that note, sport is excellent in that respect, that you can meet as equals. You can even meet, even though you don't understand the language. You don't need to know the language. You can communicate even so. [...] Sports have this character, exactly, that it somehow functions as a glue between individuals... who have little in common beyond that. (Municipal councilor 1)

Here, community and integration are presented as a product of meetings. Social differences (and possibly inequality) could be overcome through meetings on the sports ground based on the notion that within this domain people meet as equals able to communicate regardless of social or cultural conditions outside of the sporting context. Thus, social inequality is set aside, highlighting the potential of sport to be a universal means of communication and interaction. In all, meetings and relations are believed to make integration possible in the form of a social glue, holding people from distinctly different areas, backgrounds and living conditions together. This is 
a vital dimension of the discourse and knowledge contained in and underpinning the governing practices described.

\section{Bonding relations between young people and role-models facilitating learning}

In the statements analyzed, the sports-based interventions are described as sites for meetings between children and youth and formative role-models. In different ways, such meetings are understood to facilitate learning processes, or, in other words, education, resulting, presumably, in some form of refinement of the conduct of children and youth. Crucial here is the bonding relation between the role-modelling peer and role-modelled youngster. In such discourse, the coaches are positioned as conductors of social inclusion and integration in their capacity as rolemodels. A recurrent narrative, here, concerns how role-models share a similar background and experiences with the young people as well as being included in the same community. In the following excerpt, a youth coach in FFI responds to a question about his role in facilitating social inclusion and integration.

Some kids, it can be that they swear and fight a lot... and maybe having problems at home or something. So, I can be here, help out and solve things... [...] I have been in their position myself. I'm an immigrant and I came to a foreign land. Violence solves nothing. You can help out, actually... [...] I learned... and now I teach these things forward. (FFI, youth coach 2)

Here, the coach positions himself as being in the same situation as the children and youth targeted. He specifies that he is part of the same community having the same experiences and therefore has gained insights into how to behave and conduct himself. Being part of the same community, he could potentially reach out to and guide the conduct of the children and youth participating. According to this kind of statement, coaches - in their capacity as role-models and conductors of inclusion - may reach out to children and youth and potentially propel social change. The social change desired involves forming a conduct that is viable in the wider society. In this way, bonding relations within the community are used as a means of making social change and adaptation to the wider society possible. In the following excerpt, the SP manager talks about one of the coaches involved in the sports-based intervention. In this statement, the coach's influencing potential is stressed.

If you look at [coach 1], he's a boxer. He knows everyone in this area. So, he just says to a little child to "stop spitting" or "throw that in the garbage can", then the kid obeys. Because everyone knows everyone here. And it's just that... you should find what is the key for reaching out to everyone. This is what we say about... to act as a good role-model. (SP manager)

The key to reaching out here is familiar relations, to know "everybody" in the area. When the coach, acting as a role model, knows the children, he accordingly becomes a credible influencer and authority, equipped with the power to induce social change. This is, mainly, a personal quality gained from, for instance, growing up in the residential area or by gaining recognition there. On that basis, and on the basis of athletic and social achievements recognized by people in the local community, the coach embodies a local authority and facilitator of social change - a role model, a conductor of social inclusion. Credibility is the term for articulating the essence and core of the mutual and reciprocal relations established within the community. In relation to the coach described above and his co-workers, the SP manager elaborates on how it is essential that "the kids recognize us, know who we are, so it's much easier to gain credibility". In the following excerpt, the coach elaborates on this himself, underlining that shared experiences and familiarity with conditions in the residential area and community are vital for being a role-model and conductor of social inclusion, reaching out to young people.

I, like... myself... grew up in a rough area and a rough society and... so, I know and I have seen many people get in trouble. [...] When I'm in [the Area], like... when the children and youth see me and friends and so, I feel that they look up to me in a way... because I, like, made it in my 
sport and acted as a good role-model and work with children and youth. So, I believe I emit a good energy when I'm with them. [...] There are some who I have helped actually, only by talking with them. This one guy, I think of now, where I made a good impression, like... And he, himself... he says it was like a gift sent from God... me really, to him. And that I helped him, because he was... yeah, he was doing... like, drugs and so... and he was really good in football and so... And now, every time, like... when he sees me, or when I'm training or when he hears about me, he becomes energized, like I give him extra energy. And I believe so, because we have a good contact. (SP, coach 1)

Here, the coach effectively highlights four elements of being a local authority and role model governing the conduct of youth. First, he has his own biography and experience of growing up in this or a similar residential area of exclusion; second, he is a familiar figure in the area who is recognized by children and youth; third, he has a certain ability to "emit a good energy" to them, a competence and trait integral to his persona, played out in social relations; fourth, he has demonstrated his power and prowess in becoming a successful and professional athlete. Altogether, the intersection of these dynamics enables him to reach out to kids in the community and to be seen as a legitimate conductor of social change and inclusion. Notable here is how success in competitive sports seems to provide a platform for gaining credibility and acting as a role model and conductor of social inclusion. Accordingly, because the children and youth acknowledge sporting success, he becomes a legitimate authority even in non-sporting areas. In the above excerpt, the coach recalls an episode when he made a major impression. On the basis of his legitimate role as an influencer and role model, he was able to reach out to the young man in this example and facilitate social change - even suggesting that he, himself, could be described as a divine gift to a young man who was in an unfortunate situation, and that the guidance of himself as a role-model had a positive impact. Although the relation here seems to be asymmetrical (of a vertical rather than horizontal kind), this is not emphasized; instead, the bonding ties are highlighted. It is, accordingly, the bonding relation and the shared experience and mutual recognition that made the out-reach and the government of social change possible.

In the initial excerpt presented in this analysis, concerning how bridging and bonding rationales intersect in the geographical and institutional space of the intervention, the SP manager describes how, based on trust and credibility, role-models can work with young people and create values and norms in schools, to which the kids can conform and adapt. From this point of view, social inclusion and integration, by means of formative role-models, is represented as a matter of learning certain values and norms.

Role-models facilitate integration, according to this rationale, in one instance by means of demonstrating that inclusion is viable, and in another through the teaching of values and norms. First, the manager and the other role-models have succeeded in society, becoming included and integrated - something that provides a frame for reenactment: "If I can, then you can too. [...] What I want to show is that everything is possible. [...] I come from war. I got a job... I'm an immigrant." Second, the organizer of FFI explains that "the practice is like a method for integration $[. .$.$] as there are Swedish traditions, when it comes to plans and rules... and how to$ behave", something that would, supposedly, make the targeted children and youth "manage better in society as well [and] get into the norms that apply in Swedish society". Here, the coaches present in the activities and in schools embody the values and norms as well as demonstrating the path to integration. According to this rationale, they "create values locally in school and then get the kids to adapt" (SP manager). The precondition for this display and education is the idea of bonding relations and a sense of community between role-model and the role-modelled subject, notably a centerpiece enabling the governing of the conduct of young people. 


\section{DISCUSSION}

In the discourse articulated, analyzed and presented above, primarily two rationales of governing social inclusion and integration are spotlighted. First, the interventions are presented in order to provide a site for bridging meetings between young people (and associated schools and other actors), where they can get to know each other and understand youth from other social contexts better. Second, the interventions are presented as a site for meetings between young people and formative role-models, where the role-models, based on shared experiences of segregation and exclusion as well as the legitimate authority they have been granted as part of the community, can bond with and reach out to young people, reform their conduct, guide them towards inclusion and promote social integration. The potential of these rationales intersects within the geographical and institutional space of the practices and interventions. This brief summary of the discourse and knowledge being articulated specifies the rationality of the interventions promoted and instils a variety of discursive effects. Three of these are elaborated on further. Certain representations and constructions of meaning are enabled, underpinning the governing interventions; at the same time, limitations are instituted that exclude alternative constructions of meaning.

First, bonding social relations are valued primarily (if not only) as a means of reaching out to children and youth in order to induce social change and adaptation to the norms and conduct of the wider society - it is not valued or articulated as an end in itself. In contrast, an important point of recognition underlined in the scientific discourse presented is the strong emphasis on the possible progress of bonding social capital and the potential for sports-based interventions to provide a venue for bonding identity formation (cf. Spracklen et al., 2015; Walseth, 2008). Concomitantly, scientific discourse argues that the development of bridging social capital is difficult and conditioned upon a range of factors, whereas the development of bonding social capital may be easier to attain (cf. Vermeulen \& Verweel, 2009; Walseth 2008). However, in the statements examined, there are basically no examples of how sports practices are seen as arenas for using bonding relations within the community for negotiating identity between minority background and national context, or of associating bonding relations (or the strengthening of relations and networks with peers with a similar background and culture) with social integration. It is striking that the potential of bonding social relations which is acknowledged has such a moderate place in the intervention discourse on social relations and integration analyzed. Within such a discourse, promoted and embedded in governing interventions, this involves a serious risk of disregarding, and missing out on, potential integration benefits from the practices.

Second, by assessing that social inclusion and integration is a practice and process of either bridging meetings (facilitating mutual trust and understanding) with the, as it were, included majority population, or one of learning about certain Swedish majority norms and values (facilitated by bonding relations with guiding role-models), inclusion and integration become synonymous with a unilateral move of adaptation - learning about what are sometimes referred to as "Swedish values" (cf. Dahlstedt \& Eliassi, 2018). Such a rationale not only diffuses the potency of bonding relations for identity formation, but also discursively obscures the power relations embedded in these forms of interaction. Power relations between role-models and young people may be more overtly asymmetrical than those situating the meetings between young people from different schools and areas. However, relations between youth from different areas and schools are most notably characterized by socioeconomic inequality and unequal living conditions as well as by notions of normality and deviancy. It is the children and youth in the underprivileged areas and schools, the deviant areas, who are targeted and who are deemed to be in need of social inclusion and integration, and thus need to be subjected to intervention. The kind of stigmatization that may follow from obscuring these power dimensions needs to be considered in practices and integrated into the forms of knowledge imparted. 
Third, the context of intervention, as described, is one of urban, ethnic and socio-economic segregation and inequality. When spotlighting bridging meetings between people from different backgrounds and cultures alongside individual adaptation to cultural norms and conduct as the means of inclusion and integration, this implies that social integration is conceptually fixed in (and limited to) a cultural meaning. Concluding that the segregation (the tensions and conflicts), assumed to be posing a threat to social cohesion and integration has a very material and economic side, such segregation is not really possible to address (cf. Collins \& Haudenhuyse, 2015). Even the material dimensions of segregation and inequality are excluded from the discourse and meaning of inclusion and integration being promoted. Here, the anticipated benefits of practices need to be calibrated in discourse to align with the potential (and limited) effects.

According to the particular rationale of the interventions outlined, the targeted children and youth should be included and integrated on premises of cultural adaptation to the majority or in relation to perceived conceptions of pre-existing norms, capacities and identities. Inclusion, integration and identity - in such a discourse and rationale - already exist and are thus not subject to formation on conditions of the targeted children and youth themselves. With respect to the forms of governing included in the intervention, the discursive effects regulate the conditions of social inclusion and integration. Obscuring the potential in bonding identity formation and dimensions of power and inequality in interaction as well as stressing rationales of cultural adaptation, reasonably, impinge on the means of governing conducted in the intervention design. Accordingly, social inclusion and integration for children and youth become conditional upon cultural adaptation to preconceived and majority norms, capacities and identities, rather than on open identity formation for the marginalized children and youth. In this sense, the analytical findings in this empirical examination are in line with much of the previous research; however, they underscore the performative role of how the forms of discourse and knowledge embedded in practices are formative of the kind of inclusion and integration promoted, limiting and obscuring particular potentials, and problematizing even the role of social relations for combating segregation and promoting social inclusion and integration. Social inclusion and integration, in such discourse, become conceptually fixed, emphasizing in one instance bridging social relations and cultural adaptation, excluding bonding peer relations and identity formation within the marginalized community. Interestingly, this resonates quite well with and could be viewed as symptomatic of the overarching development in Swedish social and integration policy, where precisely the inward-looking, "exclusive bonding" and community-building practices of marginalized young people are problematized, viewed as self-segregating and self-excluding (cf. Ekholm \& Dahlstedt, 2018), and where the road to social inclusion for the individual leads primarily through cultural adaptation (cf. Ekholm \& Dahlstedt, 2017). The bonding potential of identity formation is obscured or viewed with suspicion in policy-making discourse (cf. Walseth, 2016). Consequently, diversity (and in that sense multiculturalism) are problematized and cultural unity is promoted as a response to the risks of the segregated society (cf. Schierup, Ålund \& Neergaard, 2017). The discursive effects outlined and described above are not limited to the specific interventions observed in this article; rather, the discourse and rationale examined here are embedded in a wider social policy context in which social inclusion and integration have been conceptualized as a matter of social interaction, relations and networks forming moral communities of shared values and norms. In this respect, the respondents, by re-articulating such a discourse in relation to the two sports-based interventions examined, align with a discourse on civic communitarianism, re-affirming images of how certain social relations, in certain ways, promote a certain form of integration.

Such conceptualizations and discourses have gained ever-increasing influence in contemporary social policy over recent decades and, as it were, have been specifically influenced by the precise (Putnamian and communitarist) language of social relations, social capital development and social 
integration that have been spotlighted in this examination in order to make visible the governmental rationale behind them (cf. Blackshaw \& Long, 2005). Analyzing the interweaving of discourse and governing, and critically how knowledge and power are intermeshed, makes it possible to understand how a language of social relations, social capital and social integration is embedded in the rationalities of governing that propel the particular sports-based interventions examined, which are characteristic of contemporary, advanced, liberal forms of social policy and (communitarian) integration in Sweden.

\section{REFERENCES}

Ålund, A., \& Schierup, C-U. (1991). Paradoxes of Multiculturalism: Essays on Swedish Society. Aldershot: Avebury.

Andersson, R. (2013). Reproducing and reshaping ethnic residential segregation in Stockholm. Geografiska Annaler, Series B, Human Geography, 95(2), 163-187. doi: 10.1111/geob.12015

Auld, C. (2008). Voluntary sport clubs: The potential for the development of social capital. In M. Nicholson \& R. Hoye (Eds.), Sport and Social Capital (pp. 143-164). London: Elsevier.

Bacchi, C. (2009). Analysing Policy: What's the Problem Represented to Be? Frenchs Forest: Pearson.

Bailey, R. (2005). Evaluating the relationship between physical education, sport and social inclusion. Educational Review, 57(1), 71-90. doi: 10.1080/0013191042000274196

Blackshaw, T., \& Long, J. (2005). What's the big idea? A critical exploration of the concept of social capital and its incorporation into leisure policy discourse. Leisure Studies, 24(3), 239-258. doi: 10.1080/0261436052000327285

Coakley, J. (2011). Youth sports: What counts as "positive development?" Journal of Sport and Social Issues, 35(3), 306-324. doi: 10.1177/0193723511417311

Coalter, F. (2007). Sport clubs, social capital and social regeneration: "ill-defined interventions with hard to follow outcomes"? Sport in Society, 10(4), 537-559. doi: 10.1080/17430430701388723

Collins, M., \& Haudenhuyse, R. P. (2015). Social exclusion and austerity policies in England: The role of sports in a new area of social polarisation and inequality? Social Inclusion, 3(3), 5-18. doi: 10.17645/si.v3i3.54

Cuskelly, G. (2008). Volunteering in community sport organizations: Implications for social capital. In M. Nicholson \& R. Hoye (Eds.), Sport and Social Capital (pp. 187-206). London: Elsevier.

Dahlstedt, M. (2009). Aktiveringens politik. Malmö: Liber.

Dahlstedt, M. \& Ekholm, D. (2019). Social exclusion and multiethnic suburbs in Sweden. In B. Hanlon \& T.J. Vicino (Eds.), The Routledge Companion to the Suburbs (pp. 163-172). New York: Routledge.

Dahlstedt, M., \& Eliassi, B. (2018). Slaget om hemmet: Värden, utanförskapanden och förorten som folkhemmets periferi. Sociologisk forskning, 55(2-3), 203-223.

Dahlstedt, M., \& Neergaard, A. (2016). Crisis of solidarity? Changing welfare and migration regimes in Sweden. Critical Sociology. doi: 10.1177/0896920516675204.

Dean, M. (2010). Governmentality. London: Sage.

Ekholm, D. (2013). Research on sport as a means of crime prevention in a Swedish welfare context. A literature review. Scandinavian Sport Studies Forum 4, 91-120. 
Ekholm, D. \& Dahlstedt, M. (2017). Football for inclusion: Examining the pedagogic rationalities and the technologies of solidarity of a sports-based intervention in Sweden. Social Inclusion, 5(2), 232-240. doi: 10.17645/si.v5i2.839

Ekholm, D. \& Dahlstedt, M. (2018). Forming the association-like organisation: On civil society, welfare provision and sport as a means of social inclusion. Journal of the Sociology of Leisure. doi: 10.1007/s41978-018-0019-5

Elmose-Østerlund, K., \& van der Roest, J-W. (2017). Understanding social capital in sports clubs: Participation, duration and social trust. European Journal for Sport and Society, 14(4), 366-386. doi: 10.1080/16138171.2017.1378479

Foucault, M. (1971). Orders of discourse. Social Science Information, 10(2), 7-30. doi: $10.1177 / 053901847101000201$

Foucault, M. (1980). Truth and power. In C. Gordon (Ed.), Power/Knowledge (pp. 109-133). Harlow: Harvester Press Limited.

Foucault, M. (1982). The subject and power. Critical Inquiry, 8(4), 777-795. doi: 10.1086/448181

Foucault, M. (2010). The Birth of Biopolitics: Lectures at the Collège de France, 1978-79. New York: Picador.

Fundberg, J. (2017). Idrottsrörelsen och samhällsnyttan - fokus på etnisk mångfald och integration. In J. Faskunger \& P. Sjöblom (Eds.) Idrottens sambällsnytta (118-130). Stockholm: Riksidrottsförbundet.

Harvey, J., Lévesque, M., \& Donnelly, P. (2007). Sport volunteerism and social capital. Sociology of Sport Journal, 24(2), 206-223. doi: 10.1123/ssj.24.2.206

Hoye, R., Nicholson, M., \& Brown, K. (2015). Involvement in sport and social connectedness. International Review for the Sociology of Sport, 50(1), 3-21. doi: 10.1177/1012690212466076

Janssens, J., \& Verweel, P. (2014). The significance of sports clubs within multicultural society. European Journal for Sport and Society, 11(1), 35-58. doi: 10.1080/16138171.2014.11687932

Morgan, H. (2013). Sport volunteering, active citizenship and social capital enhancement: What role in 'Big Society'? International Journal of Sport Policy and Politics, 5(3), 381-395. doi: 10.1080/19406940.2013.764542

Nicholson, M., \& Hoye, R. (2008) Sport and social capital: An introduction. In M. Nicholson \& R. Hoye (Eds.), Sport and Social Capital (pp. 1-20). London: Elsevier.

Philp, M. (1979). Notes on the form of knowledge in social work. The Sociological Review, 27(1), 83-111. doi: 10.1111/j.1467-954X.1979.tb00326.x

Putnam, R. D. (1993). Making Democracy Work. Princeton: Princeton University Press.

Putnam, R. D. (2000). Bowling Alone. New York: Simon \& Schuster.

Richardson Jr., J. B. (2012). Beyond the playing field: Coaches as social capital for inner-city adolescent African-American males. Journal of African American Studies, 16(2), 171-194. doi: 10.1007/s12111-012-9210-9

Rose, N. (1999). Powers of Freedom: Reframing Political Thought. Cambridge: Cambridge University Press.

Rosso, E. G. F. \& McGrath, R. (2013). Beyond recreation: Personal social networks and social capital in the transition of young players from recreational football to formal football clubs. International Review for the Sociology of Sport, 48(4), 453-470. doi: 10.1177/1012690212444409 
Schierup, C-U. (2010). "Diversity" and social exclusion in third way Sweden. The "Swedish Model" in transition, 1975-2005. TheMES. Themes on Migration and Ethnic Studies, 35, 1-46.

Schierup, C-U., Ålund, A., \& Neergaard, A. (2017). Reimagineering the nation: Crisis and social transformation in $21^{\text {st }}$ century Sweden. An introduction. In A. Ålund, C-U. Schierup \& A. Neergard (Eds.) Reimagineering the Nation: Essays on Twenty-First-Century Sweden (9-37). Frankfurt: Peter Lang.

Seippel, Ø. (2006). Sport and social capital. Acta Sociologica, 49(2), 169-183. doi: 10.1080/0261436052000327285

Sernhede, O. (2011). School, youth culture and territorial stigmatization in Swedish metropolitan Districts. Young, 19(2), 159-180. doi: 10.1177/110330881001900203

Spaaij, R. (2012) Building social and cultural capital among young people in disadvantaged communities. Sport, Education and Society, 17(1), 77-95. doi: 10.1080/13573322.2011.607913

Spracklen, K., Long, J., \& Hylton, K. (2015). Leisure opportunities and new migrant communities: Challenging the contribution of sport. Leisure Studies, 34(1), 114-129. doi: 10.1080/02614367.2014.939989

Theebom, M., Schaillée, H., \& Nols, Z. (2012) Social capital development among ethnic minorities in mixed and separate sport clubs. International Journal of Sport Policy and Politics, 4(1), $1-$ 21. $10.1080 / 19406940.2011 .627359$

Vandermeerschen, H., van Regenmortel, T., \& Scheerder, J. (2017) “There are alternatives, but your social life is curtailed": Poverty and sports participation from an insider perspective. Social Indicators Research, 133(1), 119-138. doi: 10.1007/s11205-016-1360-z

Verhagen, S., \& Boonstra, N. (2014). Bridging social capital through sports. Journal of Social Intervention: Theory and Practice 23(4), 23-38. doi: 10.18352/jsi.423

Vermeulen, J., \& Verweel, P. (2009). Participation in sport: Bonding and bridging as identity work. Sport in Society, 12(9), 1206-1219. doi: 10.1080/17430430903137886

Villadsen, K. (2008). Doing without state and civil society as universals: "Dispositifs" of care beyond the classic sector divide. Journal of Civil Society 4(3), 171-191. doi:

Walseth, K. (2008). Bridging and bonding social capital in sport: Experiences of young women with immigrant background. Sport, Education and Society, 13(1), 1-17. doi: 10.1080/13573320701780498

Walseth, K. (2016). Sport within Muslim organizations in Norway: Ethnic segregated activities as arena for integration. Leisure Studies, 35(1), 78-99. doi: 10.1080/02614367.2015.1055293

Widdop, P., Cutts, D., \& Jarvie, G. (2016) Omnivorousness in sport: The importance of social capital and networks. International Review for the Sociology of Sport 51 (5), 596-616. doi:

$10.1177 / 1012690214541101$ 